\title{
The effects of preservatives on tomato (Lycopersicon esculentum mill.) paste at varying environmental conditions
}

\begin{abstract}
Studies were carried out on United Trading Company (UTC variety) tomato paste production to determine the effects of different preservatives on the shelf-life stability of the tomato paste produced aseptically in the laboratory. The experimental tomato fruits were purchased from two local markets in Jos North during the peak of harvest in October 2014. Among the experimental tomato fruits purchased, 6 were spoiled and 44 were looking healthy. The 6 spoiled fruits were used for the isolation of fungi species causing rot in the fruits using standard mycological methods. The 44 healthy tomato fruits used for the production of the paste were weighed, washed with tap water, boiled for 20 minutes $\left(100^{\circ} \mathrm{C}\right)$. The epicarp of the boiled tomatoes was peeled and the peeled tomatoes were blended and boiled (to evaporate the water to minimal level) for 1 hour to make a paste. The paste was then cooled for 4 hours on a table. After cooling, $10 \mathrm{~g}$ of the paste was weighed each in bijou bottles which were 48 in number. Each $10 \mathrm{~g}$ of the paste weighed was given different treatment using $T_{1}(0.01 \mathrm{~g}$ salt concentration $), T_{2}(0.02 \mathrm{~g}$ salt concentration $)$, $\mathrm{T}_{3}\left(0.03 \mathrm{~g}\right.$ salt concentration), $\mathrm{T}_{4}\left(0.02 \mathrm{~g}\right.$ sodium benzoate), $\mathrm{T}_{5}$ (candle wax used in sealing the bottles) and finally $T_{6}(10 \mathrm{~g}$ of the paste without any preservative to serve as control). The experimental bottles were divided into 2 sets with each set containing 24 bottles. One set was kept in the refrigerator $\left(4^{\circ} \mathrm{C}\right)$ while the other set was kept at an ambient temperature of $25^{\circ} \mathrm{C} \pm 1^{\circ} \mathrm{C}$. The experimental pastes (treated and untreated) were evaluated for mycological quality at 1-month interval for 4 months. For every interval, 6 bottles of the paste carrying all treatments and control in each environmental condition were evaluated for mycological quality. After every evaluation, the contents of the paste were discarded. Fungi species isolated in the spoiled/untreated tomato paste include Aspergillus niger, Schizosacchomyces pombe, Brettanomyces intermidius and Fusarium sp. Treated tomato paste using candle wax and $0.03 \mathrm{~g}$ salt concentration produced the best results under both environmental conditions and thus recommended for usage by producers of tomato paste.

Keywords: preservatives, tomato, paste, fungi, environmental conditions, SDA
\end{abstract}

Volume 6 Issue 2 - 2018

Nyam MA,' Dapiya HS, ${ }^{2}$ Azi HY, ${ }^{2}$ Yanzah MR'

'Department of Plant Science and Technology, University of Jos, Nigeria

${ }^{2}$ Department of Microbiology, University of Jos, Nigeria

Correspondence: Mary Azumi Nyam, Department of Plant Science and Technology University of Jos, Nigeria, Emaildrnyamagm@gmail.com,nyamagm@yahoo.com

Received: January 30, 2018 | Published: March 27, 2018
Abbreviations: SDA, saboroud dextrose agar; CFU, colony forming unit

\section{Introduction}

Botanically, tomato (Lycopersicon esculentum Mill) is a fruit, a berry, consisting of the ovary, together with its seeds, of a flowering plant. However, the tomato has much lower sugar content than other edible fruits, and is therefore not as sweet. It belongs to the Solanaceae family widely grown throughout the warm temperate and tropical region of the world, ranking next to potatoes and sweet potatoes in importance. Numerous varieties of tomatoes are widely grown in temperate climates across the world, with greenhouses allowing its production throughout the year and in cooler areas. The plants typically grow to $1-3$ meters (3-10ft) in height and have a weak stem that often sprawls over the ground and vines over other plants. It is a perennial in its native habitat, and grown as annual in temperate climates. An average common tomato weighs approximately $100 \mathrm{~g}$.

Tomatoes have formed a very important aspect of human diet in Nigeria. They are used for a variety of dishes and are also processed in the form of various products such as tomato juice, puree, cocktail, paste, ketchup, sauce, jelly, soups, powder and tomato chutneys. Tomatoes are rich in vitamin $\mathrm{C}$ and antioxidants mainly lycopene, carotenes, organic acids and phenolics. In recent years, there has been a global trend towards the use of phytochemicals from natural resources such as vegetables, fruits, oilseeds and herbs, as antioxidants and functional ingredients. ${ }^{1}$ Consumption of beta-carotene and lycopene has been related to lower incidence of cardiovascular disease and prostate, gastrointestinal and epithelial cell cancer. ${ }^{2,3}$

Tomato is a high water-containing perishable and is very much susceptible to microbial spoilage. ${ }^{4}$ Over the years, various methods have been developed for the preservation of tomatoes such as canning, ${ }^{5}$ sun-drying and the use of chemical preservatives such as sodium benzoate and sodium metabisulfite ${ }^{6,7}$ for the preservation of tomato juice, paste, etc. In Jos, Plateau State, UTC tomato is produced throughout the year but during the peak (December), farmers spend a lot of money on the production but usually sell at a loss. The study therefore seeks methods to preserve the tomato paste naturally without preservatives, since synthetic chemicals are known to be associated with cancer.

\section{Statement of problem}

Farmers of tomato in Jos, Plateau State and Nigeria as a whole suffer losses at the peak of harvest of tomato due to an abundance of the product and a lack of method of preservation. The product however, becomes scarce during the raining season (from April) as 
a result of different diseases attacking the plant and the fruit. Such losses can be curtailed if the product is well-preserved for food security and better profit.

\section{Materials and methods}

\section{Sample collection}

Healthy tomato fruits were purchased from Farin Gada and Terminus markets of Jos North LGA, Plateau State. Out of a total of 50 fruits purchased, 6 were found to have deteriorated; they were put in a sterile polythene bag and transported to the laboratory in the University of Jos. These fruits became the experimental samples.

\section{Preparation of culture medium}

Exactly $16.25 \mathrm{~g}$ of Saboroud Dextrose Agar (SDA) was weighed and diluted in $250 \mathrm{ml}$ of distilled water. The medium was diluted in $500 \mathrm{ml}$ conical flask and autoclaved at $121 \mathrm{rpm}$ for 15 minutes. The medium was allowed to cool for 30 minutes after which $1 \mathrm{~g}$ of chloramphenicol was added into the medium and shaken vigorously and allowing it to cool. This was done to suppress the growth of bacteria. Exactly $15 \mathrm{ml}$ of the medium (SDA) was poured into 16 sterile Petri-dishes and allowed to solidify before culturing the spoiled tomatoes.

\section{Culturing of spoiled tomatoes}

Six (6) spoiled fruits were used in the isolation and identification of fungal isolates that attack ripe tomato fruits. The 6 rotten tomatoes were washed with clean water and their surfaces sterilized with $70 \%$ ethyl alcohol. A sterile scapel was used to cut $3 \mathrm{~mm} \times 3 \mathrm{~mm}$ sections of the tomato tissue. The diseased portion where the fungi are more likely to be active was cut into slices. These slices were transferred aseptically on prepared Saboroud Dextrose Agar (SDA) on 5 Petri-dishes and incubated for 4 days at an ambient temperature of $25^{\circ} \mathrm{C} \pm 1^{\circ} \mathrm{C}$. The set up was observed for 7 days to isolate the fungi associated with the fruit. Pure cultures of the isolate were made after series of inoculations into sterile Saboroud Dextrose Agar.

\section{Isolation and identification of fungi species}

The wet mount of the isolate in lactophenol in cotton blue were examined microscopically and identified based on their colonial morphology, mycelia structure, spores and associated structures. Morphological structures were identified with the aid of a light microscope.

\section{Isolation and identification of yeast species}

Gram staining was done for the identification of the yeast isolates. This examination was done by adding a drop of distilled water to prepare the smear. A portion of mycelia mat from the yeast colony was transferred into the drop of mounting fluid with the help of flame and needle. The yeast propagates were gently spread so that the yeast cell mixed with the stain of crystal violet, glucose iodine, alcohol, water and saphranin. The slides were prepared and observed under low and high power objectives of a light microscope.

\section{Production of tomato paste}

Healthy fruits were washed with tap water and rinsed to remove dirt. A knife was employed to cut the bottom of each fruit horizontally and vertically in a plus-like sign. This was done to enable the skin of the tomato fruit to peel so that the internal tissue will peel off after cooking the tomato. Water was boiled at $100^{\circ} \mathrm{C}$ and the cut tomatoes were immersed into it. The tomato fruits were gently added and boiled for 10 minutes until the skin split and peeled off. The boiled tomatoes were blended with the aid of sterile blender to produce a paste. The paste was then transferred to a clean pot and boiled for 20 minutes until a thick consistency was achieved. The paste was allowed to drain completely with the aid of a sieve in order to reduce the moisture content.

\section{Preservatives used}

Two (2) different preservatives (sodium benzoate and salt) were used to treat the tomato paste which was subjected to ambient temperature of $25^{\circ} \mathrm{C} \pm 1^{\circ} \mathrm{C}$ and $4^{\circ} \mathrm{C}$ respectively for a period of 4 months. A total of 48 bottles were used and $10 \mathrm{~g}$ of the tomato paste were weighed and each of these treatment were added to the tomato paste which were represented as: $T_{1}(0.01 \mathrm{~g}$ salt conc. $), T_{2}(0.02$ salt conc.), $\mathrm{T}_{3}(0.03$ salt conc. $), \mathrm{T}_{4}\left(0.02\right.$ sodium benzoate), $\mathrm{T}_{5}$ (candle wax $)$, $\mathrm{T}_{6}($ Control $), \mathrm{R}_{1}\left(25^{\circ} \mathrm{C} \pm 1^{\circ} \mathrm{C}\right)$, and $\mathrm{R}_{2}\left(4^{\circ} \mathrm{C}\right) .10 \mathrm{~g}$ of untreated tomato paste $\left(\mathrm{T}_{5}\right)$ was sealed in a bottle with candle wax to prevent the entry of fungi spores.

\section{Procedure for serial dilution}

$1 \mathrm{ml}$ of tomato paste was weighed with the aid of a weighing balance and was added into the first universal bottle containing $9 \mathrm{ml}$ of distilled water and shaken vigorously for 1 minute. $1 \mathrm{ml}$ of the content from the bottle was taken and injected into the second universal bottle containing $9 \mathrm{ml}$ of distilled water and shaken vigorously for 1 minute. The same procedure was repeated for $3^{\text {rd }}, 4^{\text {th }}, 5^{\text {th }}, 6^{\text {th }}$ and $7^{\text {th }}$ bottle. It was shaken after each injection of $1 \mathrm{ml}$ from the previous bottle. The whole process was carried for 7 dilutions of the tomato paste samples and repeated for another 7 universal bottles containing $9 \mathrm{ml}$ of distilled water each. After the serial dilution was carried out on the tomato paste samples. $1 \mathrm{ml}$ of the mixture from the $7^{\text {th }}$ bottle was taken with a syringe and spread on each of the 3 plates containing $15 \mathrm{ml}$ of solidified SDA medium. $1 \mathrm{ml}$ of the mixture from the $7^{\text {th }}$ dilution in the universal bottles were taken and spread on each of the Petri-dishes containing $15 \mathrm{ml}$ of solidified SDA medium.

\section{Incubation}

The 6 plates were labeled according to the sample inoculated in it. The incubator was properly cleaned up with cotton wool soaked in ethanol before placing the labeled Petri-dishes in the incubator and set at ambient temperature of $25 \pm 1^{\circ} \mathrm{C}$.

\section{Colony count and determination of colony forming units (CFU/g) of the fungi}

The grid membrane method was used for colony count which involves the ruling of lines horizontally and vertically to form grids behind the Petri-dishes and after 24 hours, the first colony count was taken. Tiny colonies formed were counted according to where they were located between the rows and columns of the grid. The colony forming unit $(\mathrm{CFU} / \mathrm{g})$ of fungi for each site was computed using the formula: colony forming units $(\mathrm{CFU})=$ Average number of colony in 3 replicates. 


\section{Results and discussion}

Results for the isolation of fungal isolates from Farin Gada and Terminus markets showed that Aspergillus niger was found present, while Penicillium sp. was found to be present in only Terminus market. Schizosaccharomyces pombe and Bretianomyces intermedius was found present in both Farin Gada market and Terminus market respectively (Table 1).

Table I Fungi associated with tomato (Lycopersicon esculentum) fruit of Farin Gada and Terminus markets after 7 days of inoculation

\begin{tabular}{|c|c|c|c|c|c|c|}
\hline Fungal Isolates & FGM $^{\prime}$ & FGM $^{2}$ & $\mathrm{FGM}^{3}$ & TM' $^{\prime}$ & TM $^{2}$ & $\mathrm{TM}^{3}$ \\
\hline Aspergillus niger & + & - & + & - & - & + \\
\hline Penicillium sp & - & - & - & + & - & - \\
\hline $\begin{array}{l}\text { Schizosaccharomyces } \\
\text { pombe }\end{array}$ & + & + & - & + & - & + \\
\hline $\begin{array}{l}\text { Bretianomyces } \\
\text { intermedius }\end{array}$ & + & + & - & + & - & + \\
\hline
\end{tabular}

Key: +, Present; -, Absent; FGM, farin gada market;TM, terminus market
Results of the treated paste kept at $25 \pm 1^{\circ} \mathrm{C}$ and $4^{\circ} \mathrm{C}$ within the period of 4 months showed that at $25 \pm 1^{\circ} \mathrm{C}$, there was presence of growth on the $T_{1} R_{1}$ treatment throughout the period of preservation which showed $100 \%$ occurrence, whereas, at $4^{\circ} \mathrm{C}$ there was no growth recorded within the period of 4 months and there was $0 \%$ frequency of occurrence. At $25 \pm 1{ }^{\circ} \mathrm{C}$, presence of growth was recorded in both the $3^{\text {rd }}$ and $4^{\text {th }}$ month of preservation which showed $50 \%$ frequency of occurrence on $T_{2} R_{1}$ treatment, no growth was recorded and there was $0 \%$ frequency of occurrence within the period of 4 months. $T_{3} R_{1}$ treatment had no record of growth within the period of 4 months occurrence likewise $T_{3} R_{2}, T_{4} R_{1}$ treatment however, showed presence of growth within the 4 months period of preservation which also had $100 \%$ frequency of growth occurrence, whereas $T_{4} R_{2}$ treatment had no record in the $3^{\text {rd }}$ and $4^{\text {th }}$ month which had $50 \%$ frequency of occurrence. $\mathrm{T}_{5} \mathrm{R}_{1}$ and $\mathrm{T}_{5} \mathrm{R}_{2}$ treatments had no record of growth which showed $0 \%$ frequency of occurrence, but in $\mathrm{T}_{6} \mathrm{R}_{1}$ and $\mathrm{T}_{6} \mathrm{R}_{2}$ had record of growth throughout the period of preservation which showed $100 \%$ frequency of occurrence as seen in Table 2 .

Table 2 Colonization by fungi species in treated and untreated tomato paste (Lycopersicon esculentum) paste after 120 days ( 4 months) of storage at $25 \pm I^{\circ} \mathrm{C}$ and $4^{\circ} \mathrm{C}$

\begin{tabular}{lllllll}
\hline Treatment & IMonth & 2Months & 3Months & 4 Months & Total & \% of occurrence \\
\hline$T_{1} R_{1}$ & + & + & + & + & 4 & 100 \\
$T_{1} R_{2}$ & - & - & + & + & 2 & 50 \\
$T_{2} R_{1}$ & - & - & + & + & 2 & 50 \\
$T_{2} R_{2}$ & - & - & + & + & 2 & 50 \\
$T_{3} R_{1}$ & - & - & - & - & 0 & 0 \\
$T_{3} R_{2}$ & - & - & - & - & 0 & 0 \\
$T_{4} R_{1}$ & + & + & + & + & 4 & 100 \\
$T_{4} R_{2}$ & - & - & + & + & 2 & 50 \\
$T_{5} R_{1}$ & - & - & - & - & 0 & 0 \\
$T_{5} R_{2}$ & - & - & - & - & 0 & 0 \\
$T_{6} R_{1}$ & + & + & + & + & 4 & 100 \\
$T_{6} R_{2}$ & + & + & + & + & 4 & 100 \\
\hline
\end{tabular}

Key: $\mathrm{T}_{1}, 0.01$ salt conc; $\mathrm{T}_{2}, 0.02$ salt conc; $\mathrm{T}_{3}, 0.03$ salt conc; $\mathrm{T}_{4}, 0.02 \mathrm{~g}$ sodium benzoate; $\mathrm{T}_{5}$, Candle wax; $\mathrm{T}_{6}$, Control; $\mathrm{R}_{1}, 25 \pm \mathrm{I}^{\circ} \mathrm{C}$ (room temp.); $\mathrm{R}_{2}, 4^{\circ} \mathrm{C}$ (refrigerator)

Results of the occurrence of fungi species isolated in treated and treatment, Schizosaccharomyces pombe was found in $\mathrm{T}_{4} \mathrm{R}_{1}$ treatment untreated tomato paste showed that Aspergillus niger was found and Bretianomyces intermedius was found in $\mathrm{T}_{6} \mathrm{R}_{2}$ treatment. present in $\mathrm{T}_{1} \mathrm{R}_{1}$ treatment. Penicillium sp was found present in $\mathrm{T}_{6} \mathrm{R}_{1} \quad$ Fusarium sp was absent in all treatments (Table 3).

Table 3 Occurrence of fungi species isolated in treated and untreated tomato (Lycopersicon esculentum) paste after 30 days ( $\mathrm{l}$ month) of storage at $25 \pm I^{\circ} \mathrm{C}$ and $4^{\circ} \mathrm{C}$

\begin{tabular}{llllll}
\hline Treatment & Aspergillus niger & Schizosaccharomyces pombe & $\begin{array}{l}\text { Bretanomyces } \\
\text { intermedius }\end{array}$ & Fusarium sp & Penicillium sp \\
\hline $\mathrm{T}_{1} \mathrm{R}_{1}$ & + & - & - & - & - \\
$\mathrm{T}_{1} \mathrm{R}_{2}$ & - & - & - & - & - \\
$\mathrm{T}_{2} \mathrm{R}_{1}$ & - & - & - & - & - \\
$\mathrm{T}_{2} \mathrm{R}_{2}$ & - & - & - & - & - \\
$\mathrm{T}_{3} \mathrm{R}_{1}$ & - & - & - & - & - \\
$\mathrm{T}_{3} \mathrm{R}_{2}$ & - & - & - & - & - \\
$\mathrm{T}_{4} \mathrm{R}_{1}$ & - & - & - & - & - \\
$\mathrm{T}_{4} \mathrm{R}_{2}$ & - & - & - & - & - \\
$\mathrm{T}_{5} \mathrm{R}_{1}$ & - & - & - & - & - \\
$\mathrm{T}_{5} \mathrm{R}_{2}$ & - & - & - & - & - \\
$\mathrm{T}_{6} \mathrm{R}_{1}$ & - & - & - & - & + \\
$\mathrm{T}_{6} \mathrm{R}_{2}$ & - & - & - & - & - \\
\hline
\end{tabular}

Key $T_{1}, 0.01$ salt conc; $T_{2}, 0.02$ salt conc; $T_{3}, 0.03$ salt conc; $T_{4}, 0.02 \mathrm{~g}$ sodium benzoate; $T_{5}$, Candle wax; $T_{6}$, Control; $R_{1}, 25 \pm 1^{\circ} \mathrm{C}$ (room temp.); $R_{2}, 4^{\circ} \mathrm{C}$ (refrigerator) 
Results of the occurrence of fungi species isolated from treated and untreated tomato paste after 60 days revealed the presence of Schizosaccharomyces pombe in $\mathrm{T}_{6} \mathrm{R}_{2}$ treatment. Bretianomyces intermedius was found present in $\mathrm{T}_{4} \mathrm{R}_{1}$ treatment and Fusarium sp was present in $\mathrm{T}_{6} \mathrm{R}_{1}$ treatment as seen in Table 4.

Results of the occurrence of fungi species in treated and untreated tomato paste showed that Penicillium sp was present $\mathrm{T}_{1} \mathrm{R}_{1}$ treatment, Schizosaccharomyces pombe was present in $\mathrm{T}_{6} \mathrm{R}_{2}$ treatment.
Bretanomyces intermedius was also found in $\mathrm{T}_{4} \mathrm{R}_{1}$ treatment. Fusarium sp was found present in $\mathrm{T}_{6} \mathrm{R}_{1}$ treatment as seen in Table 5 .

Results of the occurrence of fungi species isolated in treated and untreated tomato paste after 120 days $(4$ months $)$ of storage at $25 \pm 1^{\circ} \mathrm{C}$ and $4^{\circ} \mathrm{C}$ revealed Aspergillus niger present in $\mathrm{T}_{1} \mathrm{R}_{1}$ and $\mathrm{T}_{6} \mathrm{R}_{1}$ treatments. Penicillium sp was found in $\mathrm{T}_{2} \mathrm{R}_{1}$ treatment and Schizosaccharomyces pombe was found present in $\mathrm{T}_{4} \mathrm{R}_{1}$ and $\mathrm{T}_{6} \mathrm{R}_{2}$ treatments. Fusarium $\mathrm{sp}$ was found present in $\mathrm{T}_{4} \mathrm{R}_{2}$ treatment as seen in Table 6 .

Table 4 Occurrence of fungi species isolated in treated and untreated tomato paste after 60 days ( 2 months) of storage at $25 \pm 1^{\circ} \mathrm{C}$ and $4{ }^{\circ} \mathrm{C}$

\begin{tabular}{|c|c|c|c|c|c|}
\hline Treatment & Aspergillus niger & Penicillium sp & Schizosaccharomyces pombe & $\begin{array}{l}\text { Bretanomyces } \\
\text { intermedius }\end{array}$ & Fusarium sp \\
\hline$T_{1} R_{1}$ & - & + & - & - & - \\
\hline$T_{1} R_{2}$ & - & - & - & - & - \\
\hline $\mathrm{T}_{2} \mathrm{R}_{1}$ & - & - & - & - & - \\
\hline $\mathrm{T}_{2} \mathrm{R}_{2}$ & - & - & - & - & - \\
\hline $\mathrm{T}_{3} \mathrm{R}_{1}$ & - & - & - & - & - \\
\hline $\mathrm{T}_{3} \mathrm{R}_{2}$ & - & - & - & - & - \\
\hline $\mathrm{T}_{4} \mathrm{R}_{1}$ & - & - & - & + & - \\
\hline $\mathrm{T}_{4} \mathrm{R}_{2}$ & - & - & - & - & - \\
\hline $\mathrm{T}_{5} \mathrm{R}_{\mathrm{I}}$ & - & - & - & - & - \\
\hline $\mathrm{T}_{5} \mathrm{R}_{2}$ & - & - & - & - & - \\
\hline $\mathrm{T}_{6} \mathrm{R}_{1}$ & - & - & - & - & + \\
\hline $\mathrm{T}_{6} \mathrm{R}_{2}$ & - & - & + & - & - \\
\hline
\end{tabular}

Key: $\mathrm{T}_{1}, 0.01$ salt conc; $\mathrm{T}_{2}, 0.02$ salt conc; $\mathrm{T}_{3}, 0.03$ salt conc; $\mathrm{T}_{4}, 0.02 \mathrm{~g}$ sodium benzoate; $\mathrm{T}_{5}$, Candle wax; $\mathrm{T}_{6}$, Control; $\mathrm{R}_{1}, 5 \pm I^{\circ} \mathrm{C}$ (room temp.); $\mathrm{R}_{2}, 4^{\circ} \mathrm{C}$ (refrigerator)

Table 5 Occurrence of fungi species isolated in treated and untreated tomato paste after 90 days (4 months) of storage at $25 \pm 1^{\circ} \mathrm{C}$ and $4^{\circ} \mathrm{C}$

\begin{tabular}{|c|c|c|c|c|c|}
\hline Treatment & $\begin{array}{l}\text { Aspergillus } \\
\text { niger }\end{array}$ & $\begin{array}{l}\text { Penicillium } \\
\text { crysogenum }\end{array}$ & Schizosaccharomyces pombe & $\begin{array}{l}\text { Bretanomyces } \\
\text { intermedius }\end{array}$ & Fusarium sp \\
\hline$T_{1} R_{1}$ & - & + & - & - & - \\
\hline$T_{1} R_{2}$ & - & - & + & - & - \\
\hline $\mathrm{T}_{2} \mathrm{R}_{1}$ & - & - & - & + & - \\
\hline$T_{2}^{2} R_{2}$ & - & - & - & - & - \\
\hline $\mathrm{T}_{3} \mathrm{R}_{\mathrm{I}}^{2}$ & - & - & - & - & - \\
\hline$T_{3} R_{2}$ & - & - & - & - & - \\
\hline $\mathrm{T}_{4} \mathrm{R}_{1}$ & - & - & + & + & - \\
\hline$T_{4}^{4} R_{2}$ & - & - & - & - & - \\
\hline $\mathrm{T}_{5} \mathrm{R}_{1}^{2}$ & - & - & - & - & - \\
\hline $\mathrm{T}_{5} \mathrm{R}_{2}$ & - & - & - & - & - \\
\hline$T_{6} R_{1}$ & - & - & - & - & - \\
\hline $\mathrm{T}_{6} \mathrm{R}_{2}$ & + & - & - & - & - \\
\hline
\end{tabular}

Key: $\mathrm{T}_{1}, 0.01$ salt conc; $\mathrm{T}_{2}, 0.02$ salt conc; $\mathrm{T}_{3}, 0.03$ salt conc; $\mathrm{T}_{4}, 0.02 \mathrm{~g}$ sodium benzoate; $\mathrm{T}_{5}, \mathrm{Candle}$ wax; $\mathrm{T}_{6}, \mathrm{Control} \mathrm{R}_{1}, 25 \pm{ }^{\circ} \mathrm{C}$ (room temp.); $\mathrm{R} 2,4^{\circ} \mathrm{C}$ (refrigerator)

Table 6 Occurrence of fungi species isolated in treated and untreated tomato paste after 120 days (4 months) of storage at $25 \pm 1^{\circ} \mathrm{C}$ and $4^{\circ} \mathrm{C}$

\begin{tabular}{|c|c|c|c|c|c|}
\hline Treatment & $\begin{array}{l}\text { Aspergillus } \\
\text { Niger }\end{array}$ & $\begin{array}{l}\text { Penicillium } \\
\text { Crysogenum }\end{array}$ & Schizosaccharomyces Pombe & $\begin{array}{l}\text { Bretanomyces } \\
\text { Intermedius }\end{array}$ & Fusarium Sp \\
\hline$T_{1} R_{1}$ & + & - & - & - & - \\
\hline$T_{1} R_{2}$ & - & - & + & - & - \\
\hline$T_{2} R_{1}^{2}$ & - & + & - & - & - \\
\hline $\mathrm{T}_{2} \mathrm{R}_{2}$ & - & - & - & - & - \\
\hline $\mathrm{T}_{3} \mathrm{R}_{\mathrm{I}}^{2}$ & - & - & - & - & - \\
\hline $\mathrm{T}_{3} \mathrm{R}_{2}$ & - & - & - & - & - \\
\hline $\mathrm{T}_{4} \mathrm{R}_{1}$ & - & - & + & - & - \\
\hline $\mathrm{T}_{4}^{4} \mathrm{R}_{2}$ & - & - & - & - & + \\
\hline $\mathrm{T}_{5} \mathrm{R}_{1}^{2}$ & - & - & - & - & - \\
\hline $\mathrm{T}_{5} \mathrm{R}_{2}$ & - & - & - & - & - \\
\hline $\mathrm{T}_{6} \mathrm{R}_{1}$ & + & - & - & - & - \\
\hline $\mathrm{T}_{6} \mathrm{R}_{2}$ & - & - & + & - & - \\
\hline
\end{tabular}

Key: $\mathrm{T}_{1}, 0.01$ salt conc; $\mathrm{T}_{2}, 0.02$ salt conc; $\mathrm{T}_{3}, 0.03$ salt conc; $\mathrm{T}_{4}, 0.02 \mathrm{~g}$ sodium benzoate; $\mathrm{T}_{5}$, Candle wax; $\mathrm{T}_{6}$, Control; $\mathrm{R}_{1}, 25 \pm I^{\circ} \mathrm{C}$ (room temp.); $\mathrm{R}_{2}, 4^{\circ} \mathrm{C}$ (regenerator) 


\section{Discussion}

This research revealed that farmers of tomato can produce paste from their tomatoes during the peak period for up to four (4) months. From the results obtained using treated and untreated tomato paste kept at $25 \pm 1{ }^{\circ} \mathrm{C}$ and $4{ }^{\circ} \mathrm{C}$ within the period of 4 months, $\mathrm{T}_{3} \mathrm{R}_{1}(0.03 \mathrm{~g}$ salt conc.) which was kept at $25 \pm 1{ }^{\circ} \mathrm{C}, \mathrm{T}_{3} \mathrm{R}_{2}(0.03 \mathrm{~g}$ salt conc.) kept at $4^{\circ} \mathrm{C}$ were able to preserve the paste within the period of 4 months. $\mathrm{T}_{5} \mathrm{R}_{1}$ (candle wax) kept at $4^{\circ} \mathrm{C}$ also had great effect on the tomato paste within the 4 months period. $\mathrm{T}_{1} \mathrm{R}_{1}(0.01 \mathrm{~g}$ salt conc. $)$ kept at $25 \pm 1^{\circ} \mathrm{C}$, $\mathrm{T}_{4} \mathrm{R}_{1}(0.02 \mathrm{~g}$ sodium benzoate $)$ had no effect on the tomato paste within the 4 months period. The untreated tomato paste represented as $T_{6} R_{1}$ kept at $25 \pm 1{ }^{\circ} \mathrm{C}$ and $\mathrm{T}_{6} \mathrm{R}_{2}$ untreated tomato paste kept at $4{ }^{\circ} \mathrm{C}$ were attacked by fungi throughout the period of storage. The following treatments were able to preserve the tomato paste for a period of 2 months: $\mathrm{T}_{1} \mathrm{R}_{2}\left(0.01 \mathrm{~g}\right.$ salt conc.) kept at $4^{\circ} \mathrm{C}, \mathrm{T}_{2} \mathrm{R}_{2}(0.02 \mathrm{~g}$ salt conc.) kept at $25 \pm 1^{\circ} \mathrm{C}$ and $\mathrm{T}_{4} \mathrm{R}_{2}(0.02 \mathrm{~g}$ sodium benzoate $)$ kept at $4^{\circ} \mathrm{C}$.

This study revealed that Aspergillus niger, Penicillium sp, Scizosaccharomyces pombe, Bretanomyces intermedius, Fusarium sp were present in the affected tomato paste kept at $25 \pm 1^{\circ} \mathrm{C}$ and $4^{\circ} \mathrm{C}$. The most occurring organism in the tomato paste was yeast. Bretanomyces intermedius was the most prevalent. This organism is known to cause spoilage in beer, wine, soft drinks, pickles and ales. Schizosaccharomyces pombe is only distantly related to the species, it is osmophilic and resistant to some chemical preservatives. The ambient temperature of $25 \pm 1^{\circ} \mathrm{C}$ had no much effect on the tomato paste compared to the refrigerated tomato paste kept at $4^{\circ} \mathrm{C}$. This showed that temperature variation contributed to the spoilage of the tomato paste. A similar work was reported by Anon $^{8}$ who suggested initial contamination of raw materials was one of the variables that affected the microbial profile and shelf-life stability of canned tomato products.

UTC producers are hereby advised to use big bottles to make paste of their tomato during its peak period, use candle wax to seal the bottles or salt concentration of $0.03 \mathrm{~g}$ for $10 \mathrm{~g}$ to preserve their products for up to 4 months until when it is scarce, then they can sell their products at a profit instead of allowing them to waste.

\section{Recommendation}

From the result of this study, farmers and individuals are advised to preserve tomato in form of paste using this method of preservation, especially in developing countries like Nigeria where food scarcity is on the increase. As a result of fungi spoilage, this method can be used in preserving tomato paste in order to maintain its natural taste, colour and quality. Industries can be created by individuals or group of people in order to sustain the availability of tomato paste.

\section{Acknowledgements}

This research was supported by the Department of Plant Science and Technology. We sincerely appreciate our colleagues from the Laboratory section of the department for assisting with the materials and also in monitoring the cultures. We also appreciate our colleagues from the Department of Microbiology, University of Jos who provided insight and expertise which greatly assisted the research.

\section{Conflict of interest}

The authors whose names are listed in this research certify that they have no affiliations with any organization or entity with any financial interest and as such there is no conflict of interest among the authors of this research.

\section{References}

1. Asaduzzaman M, Haque ME, Rahman MJ, et al. Comparisons of physiochemical, total phenol, flavonoid content and functional properties in six cultivars of aromatic rice in Bangladesh. African Journal of Food Science. 2013;7(8):198-203.

2. Guil-Guerrero JL, Rebolloso-Fuentes MM. Nutrient composition and antioxidant activity of eight tomato (Lycopersicon esculentum) varieties. Journal of Food Composition and Analysis. 2009;22(2):123-129.

3. Martinez VI, Periago MJ, Provan G, et al. Phenolic compounds, lycopene and antioxidant activity in commercial varieties of tomato (Lycopersicon esculentum). Journal of Agricultural and Food Chemistry. 2002;82:323-330.

4. Mahmud RN, Islam AKMS, Inam DC. Studies of the varietal effects on the prepared tomato juice. Bangladesh Res Pub J. 2009;(3):787-795.

5. Raab CA. Canning Tomato and Tomato Products. A Pacific Northwest Extension Publication. Washington: Oregon State University; 2010. p. 1-16.

6. Nwanekezi EC, Onyali NO. Effects of Chemical Preservation on the Shelf Life of Bottled Intermediate Moisture Tomato Paste Stored at Ambient Temperature. Nigerian Food Journal. 2005;23(1):189-201.

7. Eze JI. Studies on the Effect of Different Solar Driers on the Vitamin Content of Tomato (Solanum lycopersicon). Journal of Renewable and Sustainable Energy. 2012;4(6):9-14.

8. Anon O. Micro-organisms in foods. 6th edn. Microbial Ecology of Food Commodities. New York: Academic Press; 1980;(11): 1-777. 